\title{
LED-HALOGÉN NAPSZIMULÁTOR TERVEZÉSE KISMÉRETÚ NAPELEMCELLÁK VIZSGÁLATÁHOZ
}

\section{DESIGNING PROCEDURE OF LED-HALOGEN HYBRID SOLAR SIMULATOR TO SMALL SIZE SOLAR CELL TESTING}

\author{
Koós Dániel ${ }^{1}$, Bodnár István ${ }^{2}$ \\ ${ }^{1}$ Miskolci Egyetem, Gépészmérnöki és Informatikai Kar, Energetikai és Vegyipari \\ Gépészeti Intézet Cím: H-3515 Magyarország, Miskolc-Egyetemváros, Telefon / \\ Fax: +36-20-290-1108, daniel.koos1@gmail.com \\ ${ }^{2}$ Miskolci Egyetem, Gépészmérnöki és Informatikai Kar, Elektrotechnikai és Elekt- \\ ronikai Intézet Cím: H-3515 Magyarország, Miskolc-Egyetemváros, Telefon / Fax: \\ +36-46-565-142, vegybod@uni-miskolc.hu
}

\begin{abstract}
During the experimental investigation of solar cells the quality of the illumination is essential. In case of the solar simulators the main goal is the accurate reproduction of the sunlight. Design procedure of a halogen-LED hybrid solar simulator is described in this article. One of the main goal is the compliance with the relevant standard (ASTM E972).
\end{abstract}

Keywords: solar cell, solar simulator, LED, halogen.

\section{Összefoglalás}

A napelemek laboratóriumi vizsgálata során az egyik legfontosabb tényező a megvilágítás minősége. A napfényszimulátorok esetében a cél mindig a napsugárzás lehető legpontosabb reprodukálása. Jelen cikk egy halogén-LED hibrid megvilágítással müködő napfényszimulátor tervezési lépéseit mutatja be. A tervezés során az egyik fő cél a vonatkozó szabványnak (ASTM E972) való megfelelés.

Kulcsszavak: napelem, napfényszimulátor, LED, halogén.

\section{Bevezetés}

Az első generációs napfényszimulátorok halogén-, xenon- vagy egyszerü volfrámszálas fényforrásokon és azok kombinációján alapulnak [1]. A félvezető technológia fejlődésével új típusú napfényszimulátorok jelennek meg, amelyek nagyteljesítményü LED egységeket alkalmaznak. Ezen eszközök működése energiahatékony és jó irányíthatóság jellemzi őket, továbbá különböző színü LED egységek kombinációjával a napfény spektrális szerkezete jól közelíthetö velük. Hátrányként említhető azonban, hogy tisztán LED egységeket alkalmazva nehéz elérni a szabványos vizsgálatokhoz szükséges $1000 \mathrm{~W} / \mathrm{m}^{2}$ fényintenzitás értéket [2]. E problémát küszöbölik ki a LED és hagyományos megvilágítást (pl.: halogén) kombináló megoldások [3].

\section{Tervezés}

A napfényszimulátorokra érvényes követelményekkel az American Standard for Testing and Materials (ASTM) E972-es szabványa foglalkozik [4]. Célunk e szabvány szerinti $C$ osztályú napfényszimulátor készítése, amely segítségével maxiámálisan 
$150 \times 150$ mm méretü napelem cella megfelelő megvilágítása válik lehetségessé. A konstrukció a nagyteljesítményű színes LED egységek és halogén izzók kombinációján alapul. A tervezés során a LED színcsoportok optimális megtáplálási áramerősségeinek és a halogén izzók megfelelő darabszámának, pozíciójának meghatározása a cél, fö szempontként szem előtt tartva a szabvány által elöírt spektrumszerkezetet és fényintenzitás eloszlás homogenitást.

\subsection{Spektrális egyezés tervezése}

Az egyes fényforrások abszolút spektrumszerkezetének meghatározása közvetett módon történik. A LED egységek esetében minden színre ismert a sugárzás hullámhossztartománya és a sugárzási csúcshoz tartozó hullámhossz, illetve mérések alapján a megvilágítás átlagos fényintenzitás értéke különböző megtáplálási áramerősségek esetén. Ezen adatok ismeretében az egyes LED egységek abszolút spektrumszerkezete Gauss-görbékkel jól közelíthető. A halogén lámpa spektrumszerkezetét a fekete test sugárzása alapján közelítjük, 3200 K színhőmérsékletet feltételezve. Az egyes fényforrások spektrumgörbéinek szuperpozíciója adja a napfényszimulátorra jellemző spektrumszerkezetet az adott változó paraméterek esetére. A szabvány által elöírt spektrumegyezés vizsgálat során adott hullámhossz-tartományokra kell számítani a spektrumeltérést az (1) összefüggés alapján.

$$
S E\left(\lambda_{a}-\lambda_{f}\right)=\frac{\int_{\lambda_{a}}^{\lambda_{f}} E_{N S z}(\lambda) d \lambda}{\int_{\lambda_{a}}^{\lambda_{f}} E_{A M 1,5}(\lambda) d \lambda},
$$

ahol: $S E(\lambda a-\lambda f)$ a spektrumeltérés az adott hullámhossz-tartományra [-]; $\lambda a$ a hullámhossz-tartomány alsó határa [nm]; $\lambda f$ a hullámhossz-tartomány felső határa [nm]; ENSz a napszimulátor spektrális intenzitása [W/m²/nm] és EAM1,5 napsugárzás spekt- rális intenzitása [W/m²/nm].

A spektrum optimálás során a LED színcsoportok azon megtáplálási áramerősség kombinációit keressük (a megengedett áramerősség határokon belül), amelyek esetére az (1) összefüggés alapján számítható spektrumeltérés minden hullámhossztartományra a szabványban foglalt $C$ osztálynak megfelelöen. Ezt a feladatot MATLAB környezetben oldjuk meg, ahol a program 625 áramerősség kombináció esetére végzi el az ismertetett metódust és határozza meg minden iteráció során a spektrumeltérést a vizsgált hullámhossz-tartományokra. Az 1. ábra a legjobb egyezést eredményező áramerősség kombinációk esetén mutatja az egyes fényforrások, a napszimulátor és a napsugárzás (globálsugárzás AM 1,5) spektrális eloszlását.

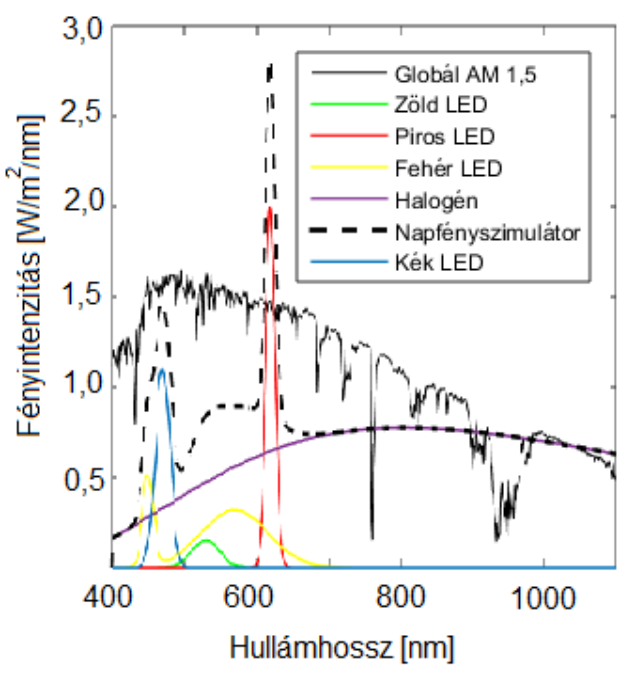

1. ábra. Optimális spektrális eloszlás

\subsection{Fényintenzitás eloszlás tervezése}

A megfelelö fényintenzitás eloszlás keresését próbamérések előzik meg. A LED egységek esetén a spektrumvizsgálathoz elvégzett fényintenzitás mérések eredményeit használjuk fel. Jelen esetben is 625 
áramerősség kombinációra számítjuk MATLAB környezetben a kialakult fényintenzitás eloszlást. A halogén lámpák esetében a változó a darabszám és a pozíció. A lámpák helye adott (a LED mátrix sarkai és oldalfelező pontjai), azonban a vízszintessel bezárt szög, a vizsgálati síktól, a LED mátrixtól vett távolság és a lámpák darabszáma (4 db vagy $8 \mathrm{db}$ ) változik. Ebben az esetben az ismertetett változók 27 kombinációjának próbája történik. Minden kombináció esetén a program számítja a két megvilágítási típus szuperpozíciójából származó fényintenzitás eloszlást és a (2) összefüggés alapján meghatározza az adott fényintenzitás eloszlás egyenetlenségét.

$$
T_{E G y}=\frac{E_{\text {max }}-E_{\text {min }}}{E_{\text {max }}+E_{\text {min }}},
$$

ahol: $T_{E g y}$ a fényintenzitás eloszlás egyenetlensége [-]; $E_{\max }$ maximális fényintenzitás $\left[\mathrm{W} / \mathrm{m}^{2}\right] ; \quad E_{\min }$ minimális fényintenzitás $\left[\mathrm{W} / \mathrm{m}^{2}\right]$. A cél a legjobb homogenitást produkáló kombináció (LED esetén áramerősségek, halogén esetén pozíció és darabszám) megtalálása. A 2. ábra szemlélteti a legjobb homogenitást mutató fényintenzitás eloszlást a vizsgálati területen.

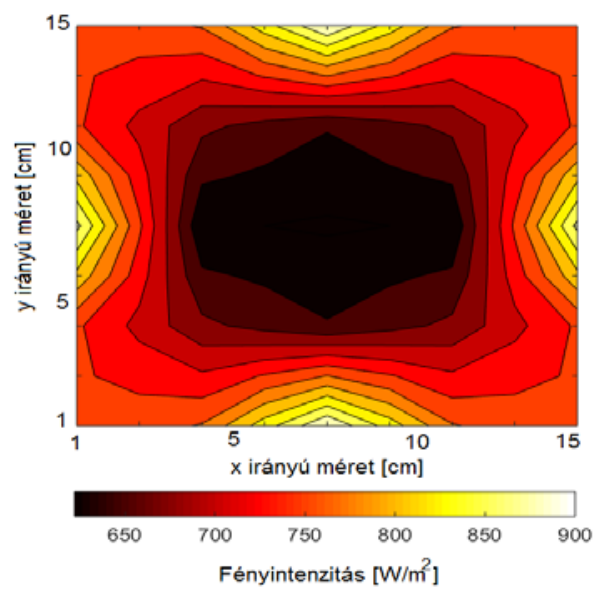

2. ábra. Legegyenletesebb fényintenzitás eloszlás a vizsgálati területen

\section{Eredmények}

\subsection{Tervezett konstrukció}

$\mathrm{Az}$ általunk tervezett napszimulátor konstrukciót $36 \mathrm{db}$, egyenként $5 \mathrm{~W}$ teljesítményü LED egység és $8 \mathrm{db}$, egyenként 50 W teljesítményü halogénizzó kombinációja és az ezeket kiszolgáló alegységek (tápegységek, szabályozó egységek hütőborda, ventilátor és váz) alkotják. A tervezés során meghatározott megtáplálási áramerősségeket a LED színcsoportok esetén (1 db LED-re értve) az 1. táblázat mutatja be. A halogén lámpák pozícióját a 2 . táblázat írja le.

1. táblázat. Különbözö színü LED egységek megtáplálási áramerösség- és feszültség értékei

\begin{tabular}{|c|c|c|}
\hline Szín & I [mA] & U [V] \\
\hline Piros & 710 & 2,5 \\
\hline Kék & 710 & 3,4 \\
\hline Zöld & 670 & 3,2 \\
\hline Fehér & 680 & 4,0 \\
\hline
\end{tabular}

2. táblázat. A halogén lámpák pozíciója

\begin{tabular}{|l|l|l|}
\hline Vízszintes távolság a & Sarkon: & Oldalt: \\
LED mátrixtól & $30 \mathrm{~mm}$ & $34 \mathrm{~mm}$ \\
\hline Vízszintessel bezárt & Sarkon: & Oldalt: \\
szög & $30^{\circ}$ & $45^{\circ}$ \\
\hline Magasság a vizsgálati & Sarkon: & Oldalt: \\
tartománytól & $75 \mathrm{~mm}$ & $60 \mathrm{~mm}$ \\
\hline
\end{tabular}

\subsection{Napfényszimulátor szabvány sze- rinti megfelelőssége}

Az említett szabvány a napfényszimulátorok osztályozását három szempont alapján végzi el. Ezen szempontok és a $C$ osztálynak megfelelő eszköz esetén a kritériumok értékei a következők: (i) megvilágítás spektrumának eltérése a napfényéhez képest: 40-200 \%; (ii) megvilágítás térbeli egyenetlensége: $\leq 10 \%$; (iii) megvilágítás időbeli egyenetlensége: $\leq 10 \%$. Mindemellett a szabványos készülékeknek minden kategória esetén biztosítani kell tudniuk a 
földfelszíni (AM 1,5) maximális $1000 \mathrm{~W} / \mathrm{m}^{2}$ átlagos fényintenzitás értéket.

$\mathrm{Az}$ általunk tervezett napszimulátor átlagos fényintenzitás értéke $910 \mathrm{~W} / \mathrm{m}^{2}$ és a fényintenzitás eloszlás homogenitása $12 \%$ a számítások alapján. A spektrális egyezést a 3. táblázat szemlélteti.

3. táblázat. Számított spektrális egyezés a vizsgált hullámhossz-tartományokban

\begin{tabular}{|c|c|}
\hline $\begin{array}{c}\text { Hullámhossz tart. } \\
{[\mu \mathrm{m}]}\end{array}$ & $\begin{array}{c}\text { Spektrális egyezés } \\
{[\%]}\end{array}$ \\
\hline $0,4-0,5$ & 12,8 \\
\hline $0,5-0,6$ & 67,0 \\
\hline $0,6-0,7$ & 82,3 \\
\hline $0,7-0,8$ & 67,9 \\
\hline $0,8-0,9$ & 81,5 \\
\hline $0,9-1,1$ & 115,3 \\
\hline
\end{tabular}

\section{Következtetések}

Munkánk során a cél egy, a szabvány szerint $C$ osztályba sorolható napszimulátor tervezése, amely alkalmas kisméretü napelemcellák vizsgálatára. Az eredmények alapján elmondható, hogy a fényintenzitás nagysága és homogenitása tekintetében kismértékben elmarad a szabvány szerinti előírástól. Ez a probléma valószínüleg a halogén lámpák pozíciójának további optimalizálásával megoldhatóvá válik. A spektrális egyezés esetén a megvilágítás minden hullámhossz-tartományban megfelel a szabvány szerinti $C$ osztály követelményeinek, kivéve a $400 \mathrm{~nm}$ - 500 nm intervallu- mot. Ez az eredmény új, alacsony hullámhosszon domináns LED egység (ultraibolya) beépítésének szükségességét jelzi. Összességében elmondható, hogy a halogén-LED hibrid megvilágítás segítségével viszonylag költséghatékony módon előállítható szabványos napfényszimulátor, azonban esetünkben e cél elérése érdekében további vizsgálatok szükségesek.

\section{Szakirodalmi hivatkozások}

[1] Wang, W.: Simulate a 'Sun' for Solar Research: A Literature Review of Solar Simulator Technology, Royal Institute of Technology, Department of Energy Technology. Swede, Stockholm, 2014.

[2] Kohraku, S., Kurakowa, K.: A Fundamental Experiment for Discrete-Wavelenght LED Solar Simulator, Solar Energy Materials \& Solar Cells 90. pp.3364-3370. 2006.

[3] Bliss, M., Betts, R., T., Gottschlag, R.: An LED-based photovoltaic measurement system with variable spectrum and flash speed, Solar Energy Materials \& Solar Cells 93. pp. 825830. 2009.

[4] ASTM International: E927-05, Standard Specification for Solar Imulation for Photovoltaic Testing, United States, 2005.

\section{Köszönetnyilvánítás}

Az Emberi Erőforrások Minisztériuma ÚNKP-17-2-I-ME/28. kódszámú Új Nemzeti Kiválóság Programjának támogatásával készült. 